\section{International Scientific Journal Theoretical \& Applied Science}

p-ISSN: 2308-4944 (print)

$$
\text { e-ISSN: 2409-0085 (online) }
$$

Year: 2015

Issue: 07

Volume: 27

Published: $30.07 .2015 \quad \underline{\text { http://T-Science.org }}$

SECTION 6. Metallurgy and energy.
Nfally Dieme Laboratory of Semiconductors and Solar Energy, Department of Physics, Faculty of Science and Technology, Cheikh Anta DiopUniversity,

Dakar, Senegal

nfallydieme@yahoo.fr fallydieme@gmail.com Moustapha Sane LSSE, DP, FST, Cheikh Anta DiopUniversity, Dakar, Senegal moustaphasane2003@yahoo.fr

Idrissa Fabe Barro

LSSE, DP, FST, Cheikh Anta DiopUniversity, Dakar, Senegal fabebarro@gmail.com

\title{
PHOTOCURRENT AND PHOTOVOLTAGE UNDER INFLUENCE OF THE SOLAR CELL THICKNESS
}

Abstract: A theoretical study of a parallel vertical junction silicon solar cell under a multi-spectral illumination in static regime has been done under impact of the thickness of this solar cell. Based on the diffusionrecombination equation, the expression of excess minority carrier density in the base was established according to the thickness. Photocurrent density and photovoltage are then deduced. The objective of this work is to show the effects of solar cell thickness on these electrical parameters.

Key words: photocurrent density, photovoltage, thickness, Vertical junction.

Language: English

Citation: Dieme N, Sane M, Barro IF (2015) PHOTOCURRENT AND PHOTOVOLTAGE UNDER INFLUENCE OF THE SOLAR CELL THICKNESS. ISJ Theoretical \& Applied Science 07 (27): 1-6.

Soi: http://s-o-i.org/1.1/TAS-07-27-1 Doi: crossef http://dx.doi.org/10.15863/TAS.2015.07.27.1

\section{Introduction}

The vertical junction solar cell is manufactured by an alternative junction base -emitter-base-emitter. Both sides have the same thickness [1]. The incident rays simultaneously touch the base, the junction and the emitter. Each base and emitter is bordered by an aluminum collector as shown in the following figure1.
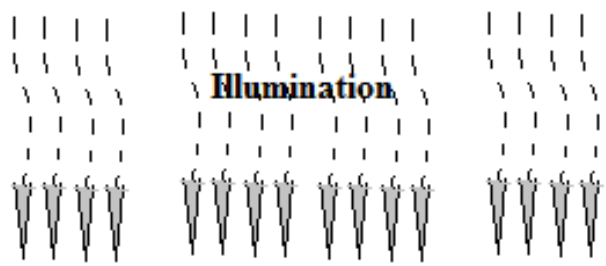

13 $\begin{array}{lll}1 & 1 & 1 \\ 1 & 1 & 1\end{array}$

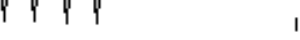

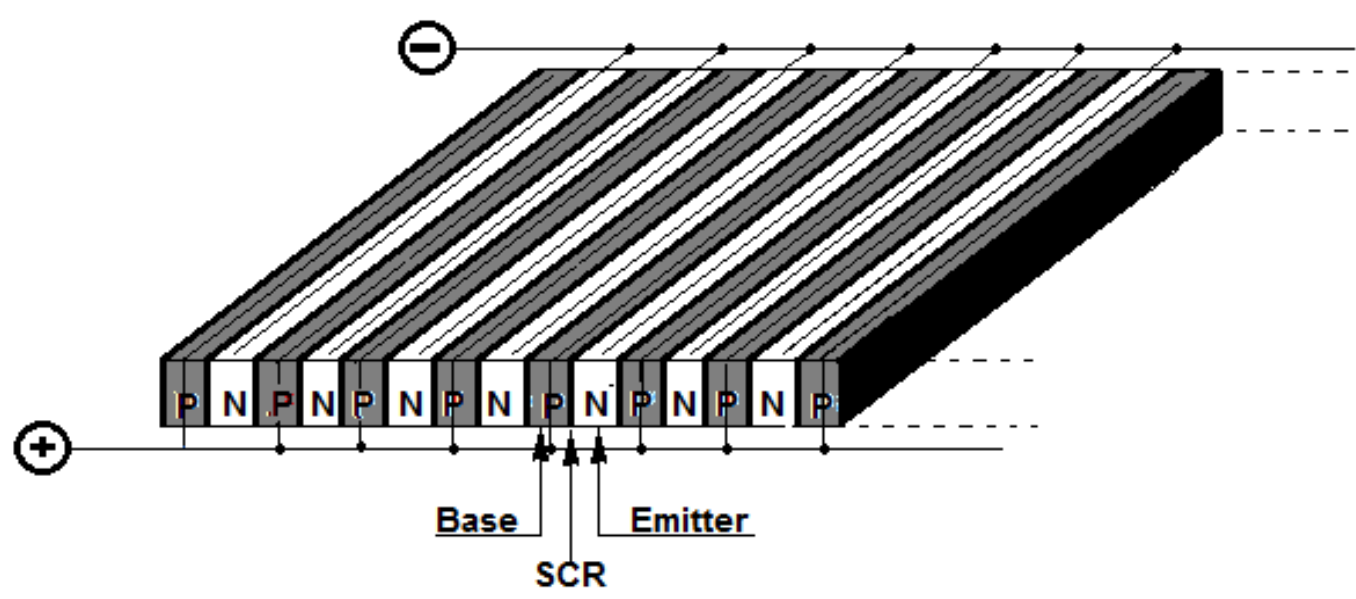

Figure 1 - Parallel vertical junction solar cell. 


\begin{tabular}{|c|c|c|c|c|c|}
\hline Impact Factor: & $\begin{array}{l}\text { ISRA (India) } \\
\text { ISI (Dubai, UAF } \\
\text { GIF (Australia) } \\
\text { JIF }\end{array}$ & $\begin{array}{l}=1.344 \\
=0.829 \\
=0.356 \\
=1.500\end{array}$ & $\begin{array}{l}\text { SIS (USA) } \\
\text { PИНЦ (Russia } \\
\text { ESJI (KZ) } \\
\text { SJIF (Morocco }\end{array}$ & $\begin{array}{l}=0.912 \\
=0.179 \\
=1.042 \\
=2.031\end{array}$ & ICV (Poland) \\
\hline
\end{tabular}

The bases are interconnected by a connecting wire to define the positive electrode and the emitters are connected together to form the negative electrode. The aim of this work is to investigate the influence of The thickness of the solar cell on electrical parameters such as photocurrent and photovoltage. Knowing the evolution of these two quantities based on the thickness is a good indicator for us to comment on the impact on the performance of solar cells.

\section{Mathematical study}

2.1. Hypotheses satisfied.

We assume that the following hypotheses are

The solar cell is illuminated along the $\mathrm{z}$ axis.

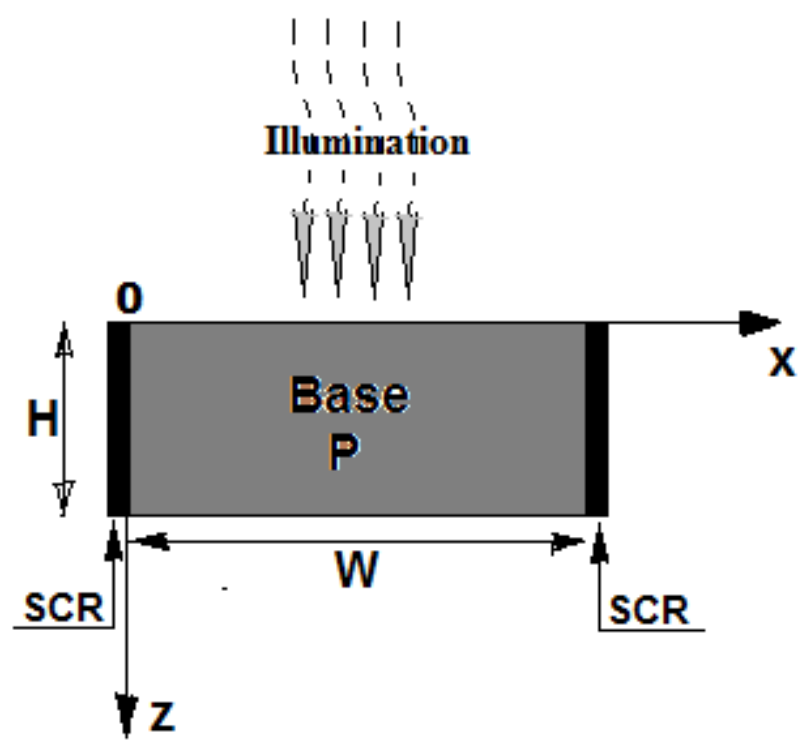

Figure 2 - Base of parallel vertical junction solar cell (thickness: $H$; width: $W=0,03 \mathrm{~cm}$ ).

- The contribution of the emitter is neglected.

- Illumination is made with polychromatic light in steady state, and is considered to be uniform on the $\mathrm{z}=0$ plane.

- There is no electric field without space charge regions.

$$
D=\mu \cdot \frac{K}{q} \cdot T
$$

with $\mathrm{q}$ as the elementary charge, $\mathrm{k}$ the Boltzmann constant and $\mathrm{T}$ temperature.

$\mathrm{G}(\mathrm{z})$ is the carrier generation rate at the depth $\mathrm{z}$ in the base and can be written as

\subsection{Density of minority charge carriers}

When the solar cell is illuminated, there are simultaneously three major phenomena that happen: generation, diffusion and recombination.

These phenomena are described by the diffusion-recombination equation obtained with:

$$
\frac{\partial^{2} n(x)}{\partial x^{2}}-\frac{n(x)}{L^{2}}=-\frac{G(z)}{D}
$$

$\mathrm{D}$ is the diffusion constant and is related to the operating temperature through the relation [2], [3]

$$
G(z)=\sum a_{i} e^{-b i z}
$$

$a_{i}$ and $b_{i}$ are obtained from the tabulated values of AM1.5 solar illumination spectrum and the dependence of the absorption coefficient of silicon with illumination wavelength.

$\mathrm{n}(\mathrm{x}), \mathrm{L}, \tau$, and $\mu$ are respectively the density of the excess minority carriers, the diffusion length, lifetime and mobility.

The solution to the equation (1) is:

$$
n(x)=A \sinh \left(\frac{x}{L}\right)+B \cosh \left(\frac{x}{L}\right)+\sum \frac{a_{i}}{D} L^{2} e^{-b i z}
$$

Coefficients A and B are determined through the following boundary conditions: at the junction $(\mathrm{x}=0)$ : 


\begin{tabular}{|c|c|c|c|c|c|c|}
\hline Impact Factor: & $\begin{array}{l}\text { ISRA (India) } \\
\text { ISI (Dubai, UAE } \\
\text { GIF (Australia) } \\
\text { JIF }\end{array}$ & $\begin{array}{l}=1.344 \\
=0.829 \\
=0.356 \\
=1.500\end{array}$ & $\begin{array}{l}\text { SIS (USA) } \\
\text { PИHЦ (Russia) } \\
\text { ESJI (KZ) } \\
\text { SJIF (Morocco) }\end{array}$ & $\begin{array}{l}=0.912 \\
=0.179 \\
=1.042 \\
=2.031\end{array}$ & ICV (Poland) & $=6.630$ \\
\hline
\end{tabular}

$$
\left.\frac{\partial n(x)}{\partial x}\right|_{x=0}=\frac{S_{f}}{D} n(0)
$$

This boundary condition introduces a parameter $\mathrm{S}_{\mathrm{f}}$ which is called recombination velocity at the junction; Sf determines the flow of the charge carriers through the junction and is directly related to the operating point of the solar cell. The higher Sf is, the higher the current density will be.

in the middle of the base $(x=W / 2)$ [5]:

$$
\left.\frac{\partial n(x)}{\partial x}\right|_{x=\frac{w}{2}}=\mathbf{O}
$$

Equation 8 illustrates the fact that excess carrier concentration reaches its maximum value in the middle of the base due to the presence of junction on both sides of the base along $\mathrm{x}$ axis (figure 1 ).

\subsection{Photocurrent density}

The photocurrent Jph is obtained from the following relation given that there is no drift current [5]:

$$
J_{p h}=\left.2 q D \frac{\partial n(x)}{\partial x}\right|_{x=0}
$$

\subsection{Photo-voltage}

The photo-voltage derives from the Boltzmann relation [6]:

$$
\mathrm{V}_{\mathrm{ph}}=\frac{k \cdot T}{q} \cdot \ln \left(N_{B} \cdot \frac{n(0)}{n_{i}^{2}}+1\right)
$$

with

$$
n_{i}=A_{n} \cdot T^{\frac{3}{2}} \cdot \exp \left(\frac{E g}{2 K T}\right)
$$

$\mathrm{n}_{\mathrm{i}}$ refers to the intrinsic concentration of minority carriers in the base,

$A_{n}$ is a specific constant of the material $\left(A_{\mathbf{n}}=3.87 \times 10^{16}\right.$ for silicon)

$\mathrm{N}_{\mathrm{B}}$ is the base doping concentration in impurity atoms

Eg is the energy gap; it is given by [3]; [4]:

$$
E g=E g_{0}-\frac{a \cdot T^{2}}{b+T}
$$

$\left(\mathrm{Eg}_{0}=1.170 \mathrm{eV} ; \quad \mathrm{a}=4.910^{-4} \mathrm{eV} \cdot \mathrm{K}^{-2} ; \quad \mathrm{b}=655 \mathrm{~K}\right.$ for silicon)

\section{Results and discussion}

In this section of our work, we present the results obtained from simulations.

\subsection{Photocurrent density}

The figure 3 and Figure 4 show the impact of the solar cell thickness on the photocurrent density.

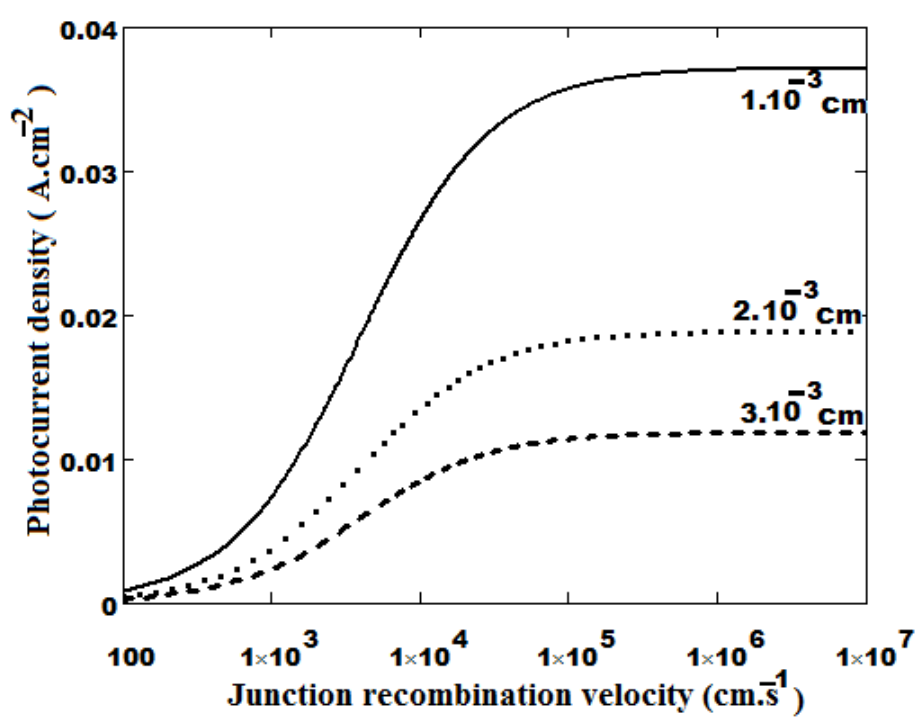

Figure 3 - Photocurrent density versus junction recombination velocity. $T=300 \mathrm{~K}$ 


\begin{tabular}{|c|c|c|c|c|c|c|}
\hline Impact Factor: & $\begin{array}{l}\text { ISRA (India) } \\
\text { ISI (Dubai, UAE } \\
\text { GIF (Australia) } \\
\text { JIF }\end{array}$ & $\begin{array}{l}=1.344 \\
=0.829 \\
=0.356 \\
=1.500\end{array}$ & $\begin{array}{l}\text { SIS (USA) } \\
\text { PИHЦ (Russia) } \\
\text { ESJI (KZ) } \\
\text { SJIF (Morocco) }\end{array}$ & $\begin{array}{l}=0.912 \\
=0.179 \\
=1.042 \\
=2.031\end{array}$ & ICV (Poland) & $=6.630$ \\
\hline
\end{tabular}

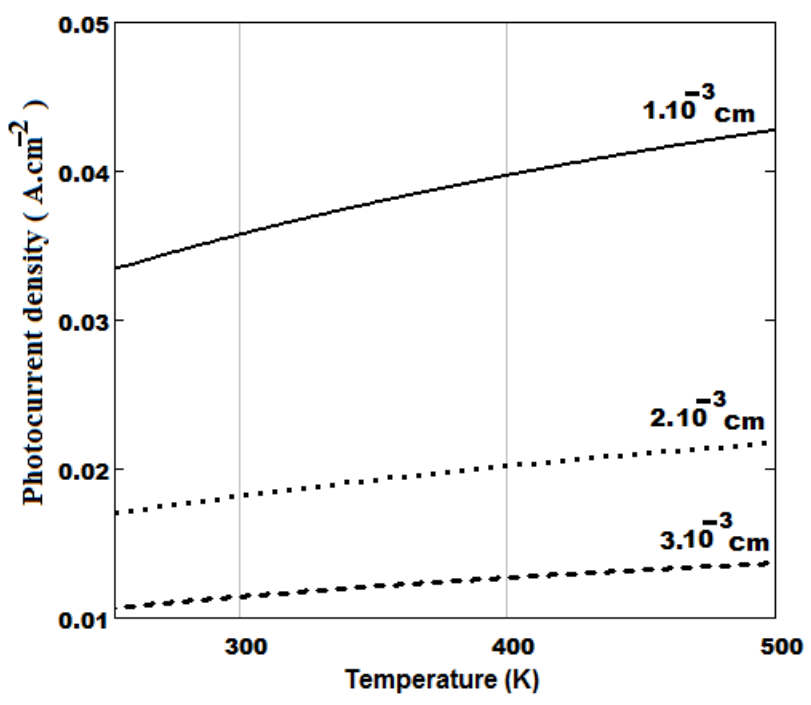

Figure 4 - Photocurrent density versus temperature $S f=10^{5} \mathrm{~cm}$.

La figure 3 shows the evolution of the photocurrent density versus junction recombination velocity for various values of solar cell thickness. It can be seen that the photocurrent increase with the junction recombination velocity. The recombination velocity at the junction reflects the stream of carriers crossing the junction [7]. For higher Sf, the carrier flow through the junction increases so that the generated photocurrent also increases: the solar cell operates near short circuit [10].

It can also be seen that the increase in the solar cell thickness causes a decrease in the photocurrent density. This same Remark is noticed in the figure5 that shows the profile of the photocurrent density versus temperature for various values of the solar cell thickness. In this figure we note that photocurrent density increases as operating temperature increase [8], [9].

\subsection{Photovoltage}

The figure5 and Figure6 show the impact of the solar cell thickness on the photocurrent density.

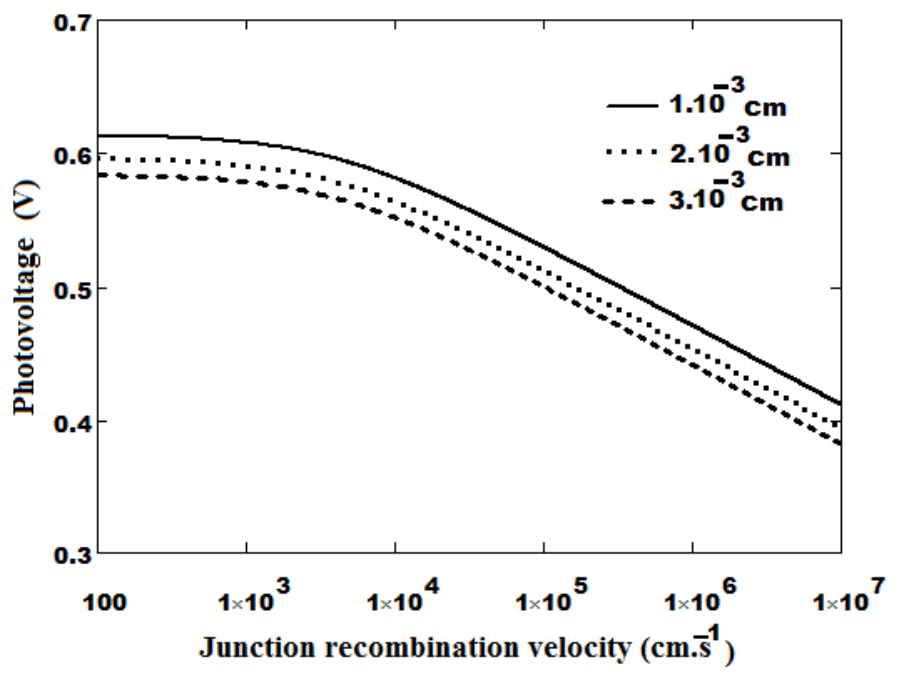

Figure 5 - Photovoltage versus junction recombination velocity $\mathrm{T}=300 \mathrm{~K}$. 


\begin{tabular}{|c|c|c|c|c|c|c|}
\hline Impact Factor: & $\begin{array}{l}\text { ISRA (India) } \\
\text { ISI (Dubai, UAE } \\
\text { GIF (Australia) } \\
\text { JIF }\end{array}$ & $\begin{array}{l}=1.344 \\
=0.829 \\
=0.356 \\
=1.500\end{array}$ & $\begin{array}{l}\text { SIS (USA) } \\
\text { PИHЦ (Russia) } \\
\text { ESJI (KZ) } \\
\text { SJIF (Morocco) }\end{array}$ & $\begin{array}{l}=0.912 \\
=0.179 \\
=1.042 \\
=2.031\end{array}$ & ICV (Poland) & $=6.630$ \\
\hline
\end{tabular}

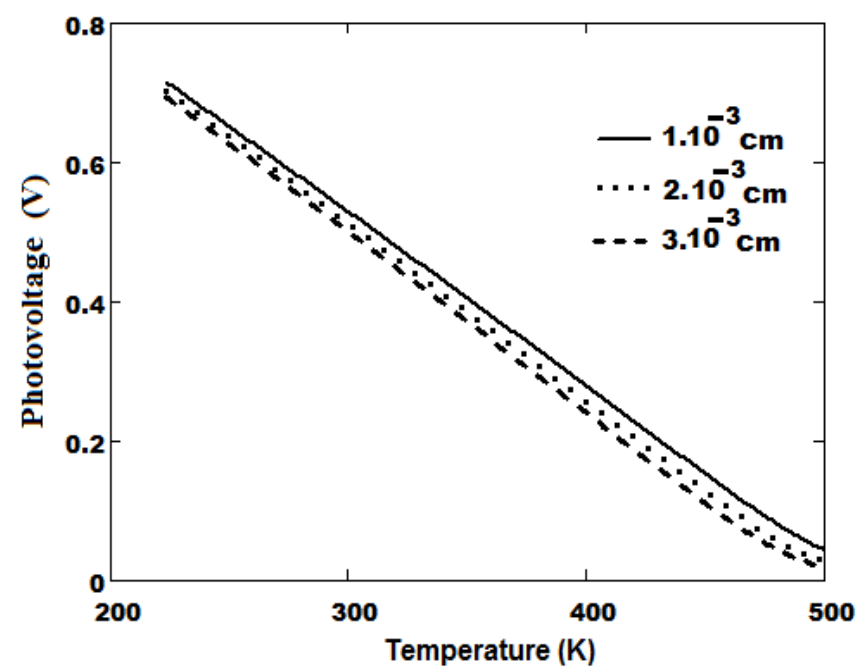

Figure 6 - Photovoltage versus temperature $S f=10^{5} \mathrm{~cm}$.

For lower junction recombination velocities, carriers flow through the junction is neglectable since carriers are stored across the junction: the photovoltage is at the maximum value (open-circuit voltage) [10]. For increasing Sf value, carriers flow through the junction increase and the stored charge cross the junction leading to a decrease of the photvoltage [7]. This decrease is all the more important than solar cell thickness is high. This simple remark is observed in the figure6. In this figure we note that photvoltage decreases as operating temperature increase [8], [9].

\subsection{Characteistc current-voltage}

Figure 7 shows the evolution of photocurrent density for different values of the solar cell thickness and in relation to photo-tension.

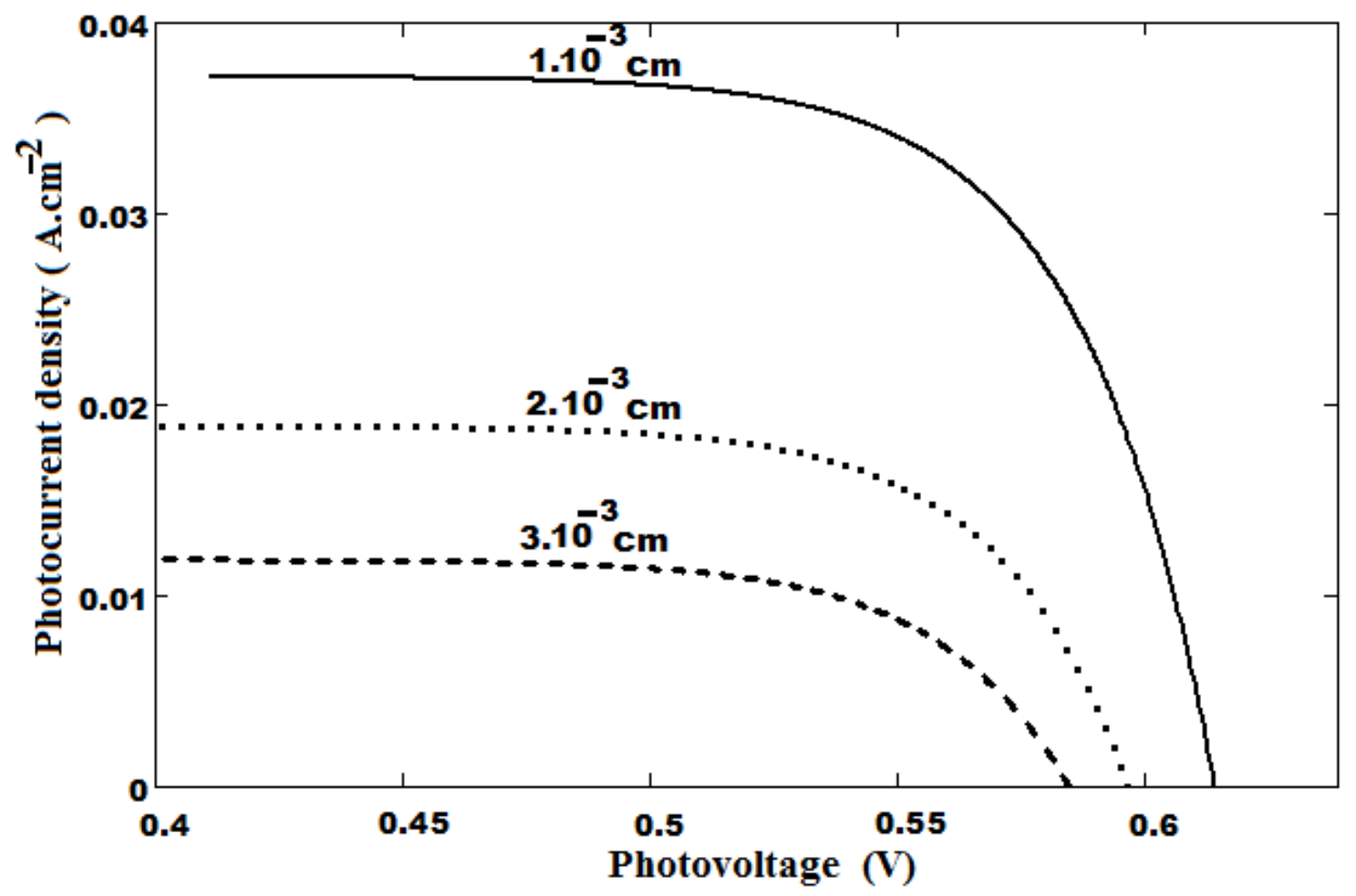

Figure 7 - Photocurrent density versus photovoltage.

Figure 7 shows that when photo-courant is maximized, photo-tension nears the zero level and vice versa. It can be noted that this figure perfectly confirms variation of the two physical quantities (photovoltage and photocurrent) in relation to solar cell thickness.

Indeed the increase in thickness increases defects in structuring and traps center for 
photogenerated electrons. Moreover high thickness increases rate imperfection of the junction. All these malfunctions are the reals causes of the decrease of photocurrent and photovoltage.

It can also be seen that when there is an increase in thickness of $\Delta \mathrm{H}=10^{-3} \mathrm{~cm}$, photovoltage can decrease by almost $3 \%$ while photocurrent can decrease by about $49 \%$.

\section{Conclusion}

A theoretical study of a vertical junction solar cell has been presented. Electrical parameters such as photocurrent density, photovoltage, have been determined and we showed the effects of solar cell. This study exhibit the fact that photocurrent density and photovoltage depend on solar cell thickness. An increase in the thickness of $\Delta \mathrm{H}=10^{-3} \mathrm{~cm}$ can prompt a decrease in photovoltage of almost $3 \%$ and a decrease in photocurrent of about $49 \%$. We can estimate that high solar cell thickness decreases performance solar panels. This study can be confirmed by studying the power under the influence of thickness.

\section{References:}

1. Dieme Nf (2015) study of the performance of a parallel vertical junction Silicon solar cell under thermal influence, Asian Academic Research Journal of Multidisciplinary, 2, $2319-280$.

2. Levy F (1995) Traité des matériaux 18 : Physique et technologie des semi-conducteurs, Presses Polytechniques et Universitaires Romandes.

3. Valkov S (1994) Electronique analogique, Edition Castéilla, Collection A.CAPLIEZ,

4. Sze SM, Kwok KN (2007) Physics of Semiconductor Devices, Third Edition, John Wiley \& Sons.

5. Ly Diallo, H., B. Dieng, I. Ly, M.M. Dione, A. Wereme, M. Ndiaye and G. Sissoko (2012) Determination of the recombination and electrical parameters of a vertical multijunction silicon solar cell. Res. J. Appl. Sci. Eng. Technol., 4 (2012) 2626-2631.

6. Ly Diallo, H., A. Wereme, A.S. Maïga and G. Sissoko (2008) New approach of both junction And back surface re recombination velocities in a 3D modeling study of a polycrystalline silicon solar cell. Eur. Phys. J. Appl. Phys., 42 (2008) 203-211.

7. M. Sane, M. Zoungrana, H. L. Diallo, G. Sahin, N. Thiam,M. Ndiaye, M. Dieng, G. Sissoko (2013) Influence of Incidence Angle on the Electrical Parameters of a vertical Silicon Solar Cell under Frequency Modulation, International Journal of Inventive Engineering and Sciences (IJIES) 1 (2013) 2319-9598.

8. Pässler R (2003) Semi-empirical descriptions of temperature dependences of band gaps in semiconductors, phys. stat. sol. 236 (2003) 710-728.

9. G. A. Landi ; P.Jenkins, D. Scheiman; R. Rafaelle (2004) Extended Temperature Solar Cell Technology Development; AIAA 2nd International Energy Conversion Engineering Conferenc August, 16- 19.

10. Thiam, M. Zoungrana, H. Ly Diallo, A Diao, N. Thiam, S. Gueye, M.M. Deme, M. Sarr and G. Sissoko (2013) Influence of Incident Illumination Angle on Capacitance of a Silicon Solar Cell under Frequency Modulation, Res.J. App. Sci. , Eng. and Technology, 5, 1123-1128. 